\title{
Prevalence of brevetoxins in prey fish of bottlenose dolphins in Sarasota Bay, Florida
}

\author{
Spencer E. Fire ${ }^{1,4, *}$, Leanne J. Flewelling ${ }^{2}$, Jerome Naar ${ }^{3}$, Michael J. Twiner ${ }^{1}$, \\ Michael S. Henry ${ }^{4}$, Richard H. Pierce ${ }^{4}$, Damon P. Gannon ${ }^{4}$, Zhihong Wang ${ }^{1}$, \\ Leigh Davidson ${ }^{1}$, Randall S. Wells ${ }^{5}$
}

\begin{abstract}
${ }^{1}$ Marine Biotoxins Program, NOAA-National Ocean Service, 219 Fort Johnson Road, Charleston, South Carolina 29412, USA
${ }^{2}$ Florida Fish and Wildlife Conservation Commission, Fish and Wildlife Research Institute, St Petersburg, Florida 33701, USA

${ }^{3}$ Center for Marine Science, University of North Carolina, Wilmington, North Carolina 28409, USA

${ }^{4}$ Mote Marine Laboratory, and ${ }^{5}$ Chicago Zoological Society, c/o Mote Marine Laboratory, 1600 Ken Thompson Parkway, Sarasota, Florida 34236, USA
\end{abstract}

\begin{abstract}
Blooms of the brevetoxin-producing dinoflagellate Karenia brevis have been linked to high mortality of bottlenose dolphins Tursiops truncatus on Florida's Gulf of Mexico coast. A clear understanding of trophic transfer of brevetoxin from its algal source up the food web to top predators is needed to assess exposure of affected dolphin populations. Prey fish constitute a means of accumulating and transferring brevetoxins and are potential vectors of brevetoxin to dolphins frequently exposed to $K$. brevis blooms. Here we report results of brevetoxin analyses of the primary fish species consumed by long-term resident bottlenose dolphins inhabiting Sarasota Bay, Florida. Fish collected during $K$. brevis blooms in 2003 to 2006 were analyzed by competitive enzyme-linked immunosorbent assay (ELISA) and had brevetoxin concentrations ranging from 4 to $10844 \mathrm{ng} \mathrm{PbTx}-3 \mathrm{eq} \mathrm{g}{ }^{-1}$ tissue. Receptor binding assay (RBA) and liquid chromatography-mass spectrometry (LC-MS) analysis confirmed toxicity and the presence of parent brevetoxins and known metabolites. Fish collected in the absence of $K$. brevis blooms tested positive for brevetoxin by ELISA and RBA, with concentrations up to $1500 \mathrm{ng}$ PbTx-3 eq $\mathrm{g}^{-1}$ tissue. These findings implicate prey fish exposed to $K$. brevis blooms as brevetoxin vectors for their dolphin predators and provide a critical analysis of persistent brevetoxin loads in the food web of dolphins repeatedly exposed to Florida red tides.
\end{abstract}

KEY WORDS: Brevetoxin · Karenia brevis $\cdot$ Tursiops truncatus $\cdot$ Harmful algal blooms $\cdot$ Algal toxins · Bottlenose dolphin $\cdot$ Marine biotoxins $\cdot$ HAB $\cdot$ Red tide

Resale or republication not permitted without written consent of the publisher

\section{INTRODUCTION}

Harmful algal blooms (HABs) have apparently increased in global distribution, intensity and frequency of occurrence over the past few decades, eliciting considerable concern over the effects of algal toxins on higher organisms including marine mammals and humans (Van Dolah 2000, Hallegraeff 2003). Marine mammals are sentinel organisms that act as barometers of coastal ocean health and can provide indicators of potential negative impacts to coastal and marine ecosystems (Bossart 2006). HABs composed of the red tide algae Karenia brevis affect Florida's Gulf of Mexico coast almost annually and have been linked to marine animal mortality events (Walker 1884, Gunter et al. 1948, Forrester et al. 1977, O'Shea et al. 1991, Landsberg \& Steidinger 1998, Mase et al. 2000, Flewelling et al. 2005). K. brevis (previously known as Gymnodinium breve and/or Ptychodiscus brevis; Daugbjerg et al. 2000) is a dinoflagellate that naturally produces a suite of potent neurotoxins, called brevetoxins, that can kill and/or accumulate in a variety of organisms, ranging from microscopic zooplankton to large marine mammals (Poli et al. 1986, Shimizu et al. 
1990, Bossart et al. 1998, Tester et al. 2000, Woofter et al. 2005). Negative impacts of elevated $K$. brevis populations (blooms) include respiratory irritation $\left(>1 \times 10^{3}\right.$

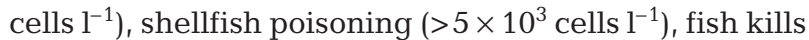
$\left(>1 \times 10^{5}\right.$ cells $\left.^{-1}\right)$ and water discoloration $\left(>1 \times 10^{3}\right.$ cells $\mathrm{l}^{-1}$ ) (Steidinger et al. 1998).

Studies examining the effects of red tide blooms on bottlenose dolphins Tursiops truncatus have investigated the link between the presence of the toxic alga Karenia brevis and large-scale dolphin mortalities and the accumulation of brevetoxin in tissues of recovered dolphin carcasses (Geraci 1989, Mase et al. 2000, Flewelling et al. 2005, Fire et al. 2007). However, findings have been inconclusive or unreported in some cases as to the ultimate source of brevetoxin exposure in these animals. In a large-scale dolphin mortality event in the Florida panhandle during 1999 and 2000, the presence of a $K$. brevis bloom coincided with over 120 dolphin deaths, but carcass decomposition precluded definitive diagnosis, and brevetoxin values in stomach contents or prey items were not reported (Mase et al. 2000). Previous dolphin mortality events have implicated $K$. brevis as the causative agent, but confounding factors such as morbillivirus infection, high tissue concentrations of environmental contaminants and a lack of corresponding prey fish data have made results inconclusive (Geraci 1989). The links between dolphins as apex predators and toxic $K$. brevis blooms have not clearly been established. Bottlenose dolphins inhabiting the same distribution range as the red tide organism are mainly piscivores (Barros \& Odell 1990, Barros \& Wells 1998) and do not feed directly on $K$. brevis, thus accumulation of brevetoxin in these animals is not likely to be a simple correlation between ambient $K$. brevis cell densities and toxin values in sampled tissues. Dolphin exposure to brevetoxins is likely dependent on a variety of factors, including, but not limited to, varying concentrations of accumulated toxin via different prey species, each with different feeding habits and varying rates of toxin accumulation, retention and metabolism. In order to better understand the fate of brevetoxins during and following a bloom, potential vectors that can transfer brevetoxin burdens to higher trophic levels must be identified.

In HABs involving other types of toxin-producing algae, planktivorous prey fish have been shown to be algal toxin vectors to coastal marine mammals (Anderson \& White 1989, Geraci et al. 1989, Lefebvre et al. 1999, Scholin et al. 2000). There is mounting evidence that prey fish act as brevetoxin vectors to Gulf of Mexico dolphins, as demonstrated in a 2004 dolphin mortality event along the Florida panhandle, in which 107 dolphin carcasses were recovered and all animals sampled had detectable levels of brevetoxin (NMFS 2004,
Flewelling et al. 2005). Although during this particular event a bloom of Karenia brevis was not detected in the mortality region concurrent with strandings, brevetoxin was present in various tissue types (17 to $104 \mathrm{ng} \mathrm{g}^{-1}$ in liver, kidney and lung) and at very high levels in stomach contents (up to $6176 \mathrm{ng} \mathrm{g}^{-1}$ ), which consisted mostly of menhaden Brevoortia spp., a planktivorous fish (Flewelling et al. 2005). Other Gulf of Mexico dolphins, sampled in Sarasota Bay, Florida from 2001 to 2003, also had elevated brevetoxin levels during $K$. brevis blooms, at concentrations reaching $78 \mathrm{ng} \mathrm{g}^{-1}$ in tissues (liver, lung, muscle and blubber), $749 \mathrm{ng} \mathrm{g}^{-1}$ in feces and up to $2900 \mathrm{ng} \mathrm{g}^{-1}$ in stomach contents (Fire et al. 2007). Though previous research has investigated the accumulation of brevetoxin in bottlenose dolphins, additional research is needed to document the levels of brevetoxin available to dolphins via their primary prey items.

The feeding habits of well-studied populations of bottlenose dolphins such as those found in Florida's Sarasota Bay area (Fig. 1) have been documented (Irvine et al. 1981, Barros \& Wells 1998). Sarasota Bay is a shallow $(<4 \mathrm{~m})$ estuarine system, semi-enclosed by barrier islands and dominated by seagrasses. The dolphins inhabiting these waters are exclusively piscivorous and feed primarily on pinfish Lagodon rhomboides, pigfish Orthopristis chrysoptera, striped mullet

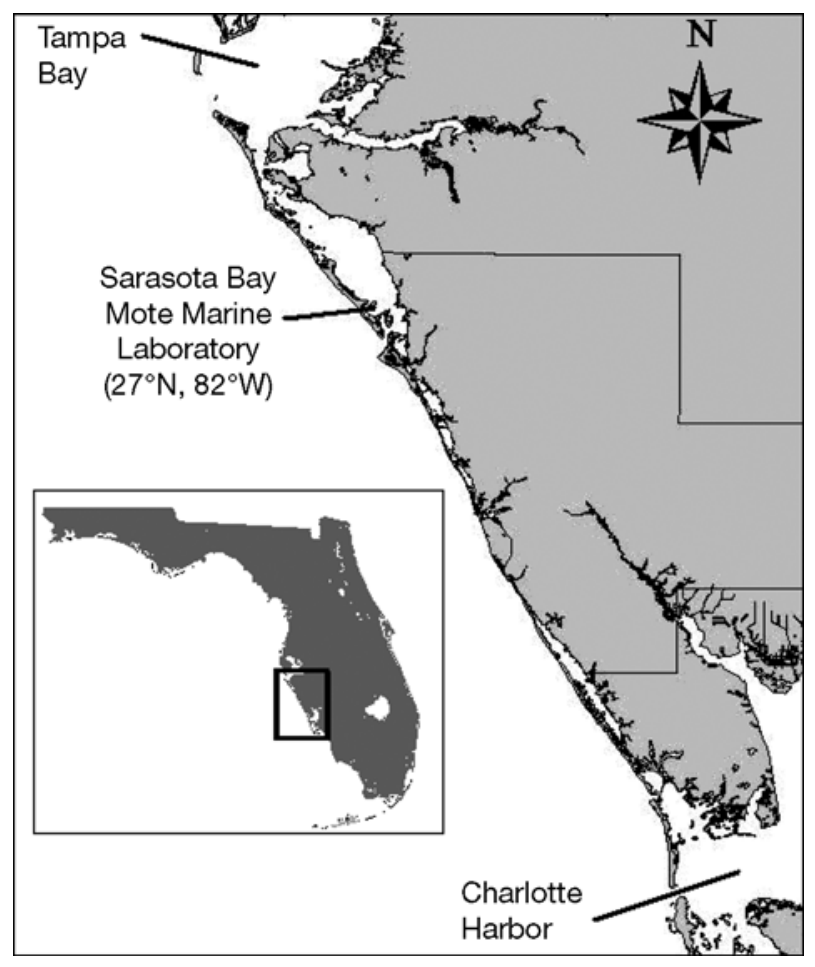

Fig. 1. Study area (Sarasota Bay and adjacent coastal waters) 
Mugil cephalus and spot Leiostomus xanthurus (Barros \& Wells 1998). Although other prey items are available to the dolphins, prey diversity in dolphin stomachs is low (1 to 3 taxa stomach ${ }^{-1}$ ), and these 4 species of fish make up over $80 \%$ of the dolphins' diet in terms of numerical abundance (Barros \& Wells 1998). As a prey group, these species of fish have widely varying feeding habits which include herbivory, carnivory, detritivory and omnivory (Collins 1985, Sutter \& Mcllwain 1987, Phillips et al. 1989, Motta et al. 1995). Given that (1) the consumption of toxic fish has been implicated as a major vector of brevetoxins to dolphins elsewhere along the Florida coast (Flewelling et al. 2005), (2) Sarasota Bay dolphins have been documented to accumulate brevetoxins (Fire et al. 2007), and (3) the Sarasota Bay area is routinely affected by nearly annual Karenia brevis blooms (Steidinger et al. 1998), it can be expected that dolphins from the present study site also have dietary brevetoxin exposure via consumption of prey fish.

To better understand this dietary exposure and the role of prey fish as vectors of brevetoxin, we collected prey fish during Karenia brevis blooms occurring between 2003 and 2006, as well as during non-bloom periods with background levels of $K$. brevis, and analyzed these specimens for the presence of brevetoxins. Our results present evidence that the primary prey fish species consumed by Sarasota Bay dolphins are potential brevetoxin vectors to these animals, and our data provide the first description of the persistence of brevetoxins in their primary prey and in a variety of other available prey species during non-bloom conditions.

\section{MATERIALS AND METHODS}

Sarasota Bay, Florida, was selected as the study site because it frequently experiences Karenia brevis blooms and supports a long-term, multi-generational, year-round resident community of bottlenose dolphins for which detailed information exists on feeding patterns (Barros \& Wells 1998, Wells 2003). During the 2003 to 2006 study period, K. brevis cell abundance data for the Sarasota Bay region were obtained and used as an indicator of the presence, absence and/or severity of $K$. brevis blooms occurring during the fish collections described below. Samples were collected by dip bucket from the upper $10 \mathrm{~cm}$ of the water column, fixed with Utermöhl's solution and examined under light microscopy to determine $K$. brevis concentrations (cells $\mathrm{l}^{-1}$ ). Daily phytoplankton monitoring data for the 2003 to 2006 period were provided by the Phytoplankton Ecology Program of Mote Marine Laboratory and were supplemented by water samples obtained during fish collections and other concurrent field studies at multiple sites in the study area (Fig. 2).

Fish and other potential prey items were collected during 5 periods between 2003 and 2006 in the Sarasota Bay region. Three of these collection periods (May to June 2003, January to May 2005 and August to September 2006) coincided with Karenia brevis blooms occurring in the study area (Fig. 2). Fish specimens collected during these blooms consisted of pinfish, pigfish, striped mullet and spot, and due to their predominance in the diet of Sarasota Bay dolphins (Barros \& Wells 1998) will be collectively referred to as primary prey fish. Additional sets of prey items were collected



Fig. 2. Karenia brevis cell abundance (cells $\mathrm{l}^{-1}$; log scale) and (triangle markers) prey fish collection dates (mo/d/yr) in the Sarasota Bay area 2003 to 2006 
during periods when blooms of $K$. brevis were not present in Sarasota Bay (June to October 2004 and January to March 2006) and consisted of primary prey fish as well as 33 other potential prey species commonly found in Sarasota Bay. Many of these additional species are known to be consumed by bottlenose dolphins throughout the Gulf of Mexico and southeastern United States (Barros \& Odell 1990) and will collectively be referred to as non-primary prey. Fish specimens were collected via purse-seine or hook and line within Sarasota Bay, and specimens were placed on wet ice until transferred to a $-20^{\circ} \mathrm{C}$ freezer upon returning to the laboratory. Fish were identified to species and measurements of body weight and standard length (SL) were recorded.

Fish specimens were prepared for toxin extraction by dissection of target tissues or by in toto homogenization of whole specimens. Sample types available for brevetoxin analysis included muscle, liver, gill, stomach contents, whole viscera (all organs in intracoelomic cavity) or whole fish. For a few small fish specimens collected from the same location and time, tissues were pooled according to species to increase the amount of material available for toxin extraction. Each pooled sample is referred to hereafter as an individual fish specimen and was treated as a single sample for analytical purposes. For a subset of pinfish, pigfish and spot, total tissue mass for viscera and muscle in each specimen was recorded in order to estimate whole-fish brevetoxin burdens. Brevetoxins were extracted by homogenizing the sample material in 3 volumes of acetone, followed by sonication and centrifugation at $3000 \times g$. The supernatant was evaporated and resuspended in $85 \%$ methanol, followed by 2 solvent partitioning steps with hexane. The methanolic fraction was collected and passed through a $0.45 \mu \mathrm{m}$ hydrophilic polypropylene syringe-driven filter (Pall Life Sciences). The filtrate was evaporated and the remaining residue was resuspended in $100 \%$ methanol. Extracts were stored at $-20^{\circ} \mathrm{C}$ until analysis.

A competitive enzyme-linked immunosorbent assay (ELISA) was used as the primary source of brevetoxin quantification and followed protocols described by Naar et al. (2002). This type of immunological assay provides sufficient sensitivity to quantitatively detect very low brevetoxin concentrations by means of structural affinity for a target epitope and is effective as a rapid screening method (Van Dolah \& Ramsdell 2001). This method utilizes polyclonal anti-brevetoxin antibodies that recognize all brevetoxin congeners and metabolites with a brevetoxin-B-type structure. ELISA results expressed as 'brevetoxins' refer to all brevetoxin congeners that respond to these antibodies, and concentrations detected are in nanograms of PbTx-3 equivalents per gram of tissue (ng PbTx-3 eq $\mathrm{g}^{-1}$ ). The
ELISA limit of detection of brevetoxin in the present study was $3 \mathrm{ng} \mathrm{PbTx}-3$ eq $^{-1}$.

Selected samples were also analyzed by a receptor binding assay (RBA), utilizing microplate format methods outlined by Van Dolah et al. (1994). Briefly, the RBA measures binding competition between radiolabeled brevetoxin-3 and brevetoxin in samples for binding to voltage-gated sodium channels in rat brain synaptosomes, the pharmacological target of brevetoxins. In contrast to the ELISA, which quantifies brevetoxins based on structure, the RBA quantifies brevetoxins based on their affinity for a specific cell membrane receptor, in effect estimating the total toxic potency of a sample. The RBA limit of detection of brevetoxin in the present study was $70 \mathrm{ng}$ PbTx-3 eq $\mathrm{g}^{-1}$.

A subset of samples that tested positive by ELISA underwent additional analysis by 2 methods of liquid chromatography-mass spectrometry (LC-MS). In LCMS, brevetoxin congeners are chromatographically separated and individually quantified by a mass-tocharge ratio $(\mathrm{m} / \mathrm{z})$ relative to standard reference material, and this method was utilized as a confirmatory method for ELISA and RBA data. Selected samples were initially analyzed for PbTx-3 following LC-MS methods described by Plakas et al. (2004), using a ThermoFinnigan AqA HPLC-MS equipped with an AqA single quad system, with a limit of quantification of $300 \mathrm{ng} \mathrm{g}^{-1}$. Further analysis of additional brevetoxin congeners, including known metabolites, was performed using an Agilent 1100 LC system (Agilent Technologies) coupled to an Applied Biosystems/MDS Sciex 4000 Q TRAP hybrid triple quadrupole/linear ion trap mass spectrometer equipped with a Turbo $\mathrm{V}^{\mathrm{TM}}$ ionization interface (Applied Biosystems). LC separation was performed on a Luna C8(2), $5 \mu \mathrm{m}, 2.0 \times$ $150 \mathrm{~mm}$ column (Phenomenex). The mobile phase consisted of water and acetonitrile in a binary system, with $0.1 \%$ acetic acid as an additive. The elution gradient was $1 \mathrm{~min}$ of $42 \%$ acetonitrile, linear gradient to $80 \%$ acetonitrile at $22 \mathrm{~min}, 95 \%$ acetonitrile at $27 \mathrm{~min}$, held for $5 \mathrm{~min}$, then returned to initial conditions at $33 \mathrm{~min}$ and held for $7 \mathrm{~min}$ before next injection. The flow rate was $0.2 \mathrm{ml} \mathrm{min}^{-1}$. Brevetoxin congeners were detected in positive ion mode using the multiple reaction monitoring (MRM) method. Twenty-two MRM transitions were monitored, which covered the following brevetoxin congeners: $\mathrm{PbTx}-1,-2,-3,-7$ and -9 and hydrolysis products of $\mathrm{PbTx}-2,-3,-7$ and -9 (A-ring open brevetoxin derivatives; Abraham et al. 2006), cysteine$\mathrm{PbTx}-\mathrm{B} / \mathrm{A}$ and their sulfoxides (Wang et al. 2004) (also known as BTX-B2; Murata et al. 1998) and cysteinePbTx sulfoxide (Plakas et al. 2002) for cysteine-B-type backbone brevetoxin sulfoxide conjugate, cysteinePbTx (Plakas et al. 2002) and desoxy-BTX-B2 (Bottein 
Table 1. Brevetoxin concentrations detected in primary prey fish species collected during and in the absence of Karenia brevis blooms. Concentrations (mean and range) expressed in nanograms PbTx-3 equivalents per gram sample (ng PbTx-3 eq $\mathrm{g}^{-1}$ ). nd: not detected; -: no test made or no sample available

\begin{tabular}{|c|c|c|c|c|c|c|c|c|}
\hline $\begin{array}{l}K . \text { brevis } \\
\text { blooms }\end{array}$ & Species & $\begin{array}{l}\text { \% PbTx-positive } \\
\text { fish (n) }\end{array}$ & Muscle & Viscera & Liver & Gill & $\begin{array}{l}\text { Stomach } \\
\text { contents }\end{array}$ & $\begin{array}{l}\text { Whole } \\
\text { fish }\end{array}$ \\
\hline \multirow[t]{4}{*}{ Present } & Pinfish & $93(30)$ & $\begin{array}{c}62 \\
\text { (11 to } 197)\end{array}$ & $\begin{array}{c}1313 \\
\text { (4 to } 5188)\end{array}$ & $\begin{array}{c}1378 \\
\text { (475 to } 3759)\end{array}$ & $\begin{array}{c}891 \\
\text { (42 to } 7472)\end{array}$ & $\begin{array}{c}727 \\
\text { (202 to } 2263)\end{array}$ & - \\
\hline & Pigfish & $100(11)$ & $\begin{array}{c}57 \\
\text { (6 to } 365)\end{array}$ & $\begin{array}{c}610 \\
\text { (181 to } 1456)\end{array}$ & $\begin{array}{c}1196 \\
\text { (267 to 2035) }\end{array}$ & $\begin{array}{c}947 \\
\text { (77 to } 2671)\end{array}$ & $\begin{array}{c}812 \\
\text { (203 to } 1424)\end{array}$ & - \\
\hline & Mullet & $100(23)$ & $\begin{array}{c}7 \\
(5 \text { to } 9)\end{array}$ & $\begin{array}{c}81 \\
\text { (11 to } 258)\end{array}$ & $\begin{array}{c}763 \\
\text { (147 to 1838) }\end{array}$ & $\begin{array}{c}44 \\
\text { (26 to } 113)\end{array}$ & $\begin{array}{c}121 \\
\text { (79 to } 168)\end{array}$ & - \\
\hline & Spot & $100(10)$ & $\begin{array}{c}57 \\
\text { (21 to } 149)\end{array}$ & $\begin{array}{c}1982 \\
\text { (743 to 3282) }\end{array}$ & $\begin{array}{c}3981 \\
\text { (3117 to } 4846)\end{array}$ & $\begin{array}{c}869 \\
\text { (809 to } 930)\end{array}$ & $\begin{array}{c}6350 \\
(1855 \text { to } 10844)\end{array}$ & - \\
\hline \multirow[t]{4}{*}{ Absent } & Pinfish & $88(16)$ & $\begin{array}{c}7 \\
(3 \text { to } 14)\end{array}$ & $\begin{array}{c}68 \\
(15 \text { to } 143)\end{array}$ & 507 & nd & 45 & 456 \\
\hline & Pigfish & $90(10)$ & nd & $\begin{array}{c}87 \\
\text { (45 to } 143)\end{array}$ & $\begin{array}{c}293 \\
\text { (21 to } 1047)\end{array}$ & 34 & $\begin{array}{c}233 \\
\text { (202 to } 263)\end{array}$ & 98 \\
\hline & Mullet & $67(3)$ & nd & $\begin{array}{c}156 \\
\text { (91 to } 222)\end{array}$ & - & - & - & - \\
\hline & Spot & $100(5)$ & $\begin{array}{c}9 \\
\text { (5 to } 12)\end{array}$ & $\begin{array}{c}303 \\
\text { (7 to } 753)\end{array}$ & - & - & - & - \\
\hline
\end{tabular}

Dechraoui et al. 2007) for cysteine B-type backbone brevetoxin conjugate, glutathione-PbTx-B, glycinecysteine-PbTx-B (Wang et al. 2004), oxidized-PbTx-2 and its hydrolysis product (Abraham et al. 2006). Nitrogen was used as the nebulization gas, turbo gas (at transmission electron microsope, $\mathrm{TEM}, 365^{\circ} \mathrm{C}$ ), curtain gas and collision gas. The ion spray voltage was $5 \mathrm{kV}$, the declustering potential was $64 \mathrm{~V}$, and the collision energy was adjusted ( 25 to $50 \mathrm{eV}$ ) as appropriate for each toxin congener. Six PbTx-3 standards (1 to $250 \mathrm{ng}$ $\left.\mathrm{ml}^{-1}\right), 1 \mathrm{PbTx}-9$ standard $\left(25 \mathrm{ng} \mathrm{ml}^{-1}\right), 1$ hydrolysis product of $\mathrm{PbTx}-3$ standard $\left(100 \mathrm{ng} \mathrm{ml}^{-1}\right)$ and 1 cysteine-PbTx-B sulfoxide standard $\left(10 \mathrm{ng} \mathrm{ml}^{-1}\right)$ were used. Due to the limited availability of the standards, some toxin congeners were semi-quantified with a single standard. Concentrations of cysteine-adducts were estimated from cysteine-PbTx-B sulfoxide standard. The LC-MS analysis signal-to-noise ratio was ca. 40 for injection of $5 \mu \mathrm{l}$ of $1 \mathrm{ng} \mathrm{ml}^{-1}$ of PbTx-3, ca. 70 for injection of $5 \mu \mathrm{l}$ of $25 \mathrm{ng} \mathrm{ml}^{-1}$ of PbTx-9, ca. 700 for injection of $5 \mu \mathrm{l}$ of $100 \mathrm{ng} \mathrm{ml}^{-1}$ of hydrolysis product of $\mathrm{PbTx}-3$ and ca. 67 for injection of $5 \mu \mathrm{l}$ of $10 \mathrm{ng} \mathrm{ml}^{-1}$ of cysteine$\mathrm{PbTx}$-B sulfoxide.

\section{RESULTS}

Over the course of the present study (2003 to 2006), ambient densities of Karenia brevis fluctuated widely in concentration, ranging from below the detection

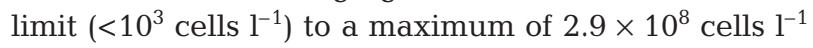
(Fig. 2). This period encompassed $4 K$. brevis blooms in the Sarasota Bay area, occurring January to October 2003, January to February 2004, January to December 2005 and July to December 2006. Three of these blooms co-occurred with primary prey fish collections, with ambient cell densities of $K$. brevis ranging in con-

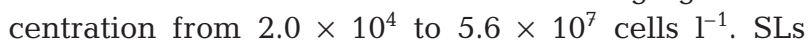
recorded for primary prey fish indicated that nearly all specimens collected were adults (mean SL: pinfish = $125 \mathrm{~mm}$, pigfish $=122 \mathrm{~mm}$, mullet $=270 \mathrm{~mm}$ and spot $=$ $176 \mathrm{~mm}$ ). These measurements fall within the size ranges reported for fish recovered from Sarasota Bay dolphin stomachs, the majority of which were also adult fish (Barros \& Wells 1998). For primary and nonprimary prey collected in the absence of a $K$. brevis bloom, cell concentrations were generally at or below the detection limit of $1 \times 10^{3}$ cells $^{-1}$.

\section{Brevetoxins in primary prey fish collected during Karenia brevis blooms}

Karenia brevis blooms were observed in Sarasota Bay concurrently with 3 of the primary prey fish collection periods; May to June 2003, January to May 2005 and August to September 2006. Analysis of these fish detected brevetoxins in $100 \%$ of sampled mullet $(\mathrm{n}=$ $23)$, pigfish $(\mathrm{n}=11)$ and spot $(\mathrm{n}=11)$ and in $93 \%$ of pinfish $(\mathrm{n}=30)$ (Table 1$)$. In total, $97 \%(\mathrm{n}=74)$ of all primary prey fish collected during $K$. brevis blooms were positive for brevetoxin in at least one sample/tissue type. Brevetoxins were detected in all whole viscera samples and in the majority of muscle, liver, gill and 
stomach samples tested, with concentrations in PbTxpositive samples ranging between 4 to $10844 \mathrm{ng} \mathrm{PbTx}-$ 3 eq $\mathrm{g}^{-1}$. All whole viscera samples $(\mathrm{n}=49)$ were positive for brevetoxin, with concentrations ranging between 4 and 5188 (mean = 981) ng PbTx-3 eq g $^{-1}$. The majority of liver and stomach contents samples were positive for brevetoxins $(92 \%, \mathrm{n}=25)$ and had brevetoxin concentrations comparable to whole viscera (147 to 4846 and 79 to 10844 ng PbTx-3 eq g ${ }^{-1}$, respectively). Brevetoxin was also detected frequently in gill samples $(91 \%, \mathrm{n}=35)$ with concentrations between 26 and 7472 ng PbTx-eq ${ }^{-1}$. Brevetoxin concentrations in muscle samples were consistently lower than those detected in viscera, stomach, liver and gill samples for all species tested. Of the available muscle samples analyzed, $70 \%(n=73)$ were positive for brevetoxin, with concentrations ranging between 5 and 365 (mean = 53) ng PbTx-3 eq g ${ }^{-1}$. Brevetoxin concentrations in viscera were highest in spot, followed by pinfish, pigfish and striped mullet (mean $=1982,1313$, 610 and $81 \mathrm{ng}$ PbTx-eq $\mathrm{g}^{-1}$, respectively), with the highest viscera concentration detected in pinfish (5188 ng PbTx-eq g $^{-1}$ )

RBA analysis of ELISA-positive viscera samples detected brevetoxins in 15 of 25 samples, with detected concentrations ranging from 199 to $1566 \mathrm{ng}$ PbTx-3 eq $\mathrm{g}^{-1}$ (Table 2). The RBA did not detect brevetoxins in samples with a corresponding ELISA concentration of $<200 \mathrm{ng}$ PbTx-3 eq $\mathrm{g}^{-1}$, though the detection limit for the RBA in the present study was $80 \mathrm{ng}$ PbTx3 eq $\mathrm{g}^{-1}$. Although RBA measurements for these samples were generally between 30 and $60 \%$ of the corresponding ELISA brevetoxin concentration, the data obtained by RBA and ELISA were well correlated $\left(\mathrm{R}^{2}=\right.$ 0.830; Fig. 3).

LC-MS analyses of ELISA-positive viscera samples unambiguously confirmed the presence of parent brevetoxins (PbTx-3) as well as 6 known brevetoxin metabolites (hydrolysis products of PbTx-3 and -7, cysteine-PbTx-B/A and their sulfoxides) (Table 2). PbTx-3 was confirmed in all 8 samples tested, at concentrations ranging between 1.8 and $25 \mathrm{ng} \mathrm{g}^{-1}$. Brevetoxin

Table 2. Comparison of ELISA, RBA and LC-MS results for brevetoxins in viscera of selected fish collected during Karenia brevis blooms (ng PbTx-3 eq $\mathrm{g}^{-1}$ for ELISA and RBA, ng g ${ }^{-1}$ for LC-MS). nd: not detected; +: qualitatively determined to be present (positive); nt: not tested

\begin{tabular}{|c|c|c|c|c|c|c|c|c|c|c|}
\hline \multirow[t]{2}{*}{ Sample } & \multirow{2}{*}{$\begin{array}{c}\text { Date } \\
(\mathrm{mo} / \mathrm{d} / \mathrm{yr})\end{array}$} & \multirow[t]{2}{*}{ ELISA } & \multirow[t]{2}{*}{ RBA } & \multirow[b]{2}{*}{$\begin{array}{l}\text { Parent toxin } \\
\text { PbTx-3 }\end{array}$} & \multicolumn{4}{|c|}{$\begin{array}{l}\text { - LC-MS } \\
\text { Brevetoxin metabolites }\end{array}$} & \multirow[b]{2}{*}{$\begin{array}{c}\text { Cysteine- } \\
\text { PbTx-A }\end{array}$} & \multirow[b]{2}{*}{$\begin{array}{c}\text { Cysteine- } \\
\text { PbTx-A } \\
\text { sulfoxide }\end{array}$} \\
\hline & & & & & $\begin{array}{c}\text { Hydrolysis } \\
\text { product of } \\
\text { PbTx-3 }\end{array}$ & $\begin{array}{c}\text { Bydrolysis } \\
\text { product of } \\
\text { PbTx-7 }\end{array}$ & $\begin{array}{l}\text { Brevetoxin n } \\
\text { Cysteine- } \\
\text { PbTx-B }\end{array}$ & $\begin{array}{c}\text { metabolites } \\
\text { Cysteine- } \\
\text { PbTx-B } \\
\text { sulfoxide }\end{array}$ & & \\
\hline Pinfish & $5 / 19 / 03$ & 3628 & 1566 & 25 & 3.2 & + & 291 & 1822 & 3.1 & 204 \\
\hline Spot & $3 / 15 / 05$ & $\begin{array}{l}3282 \\
2738 \\
2097 \\
2070 \\
2057 \\
1963\end{array}$ & $\begin{array}{c}1357 \\
1222 \\
1324 \\
706 \\
713 \\
862\end{array}$ & $\begin{array}{c}6.3 \\
2.3 \\
7.8 \\
1.8 \\
3 \\
1.9\end{array}$ & $\begin{array}{l}\text { nd } \\
\text { nd } \\
\text { nd } \\
\text { nd } \\
\text { nd } \\
2.4\end{array}$ & $\begin{array}{l}+ \\
+ \\
+ \\
+ \\
+ \\
+\end{array}$ & $\begin{array}{c}612 \\
29 \\
319 \\
17 \\
232 \\
508\end{array}$ & $\begin{array}{c}1354 \\
829 \\
885 \\
281 \\
1692 \\
1225\end{array}$ & $\begin{array}{l}8.5 \\
1.2 \\
3.7 \\
\text { nd } \\
9.3 \\
8.3\end{array}$ & $\begin{array}{c}236 \\
70 \\
107 \\
32 \\
438 \\
63\end{array}$ \\
\hline Pinfish & $5 / 19 / 03$ & $\begin{array}{l}1829 \\
1453\end{array}$ & $\begin{array}{c}1038 \\
538\end{array}$ & 3.6 & 4.9 & nt & 50 & 764 & 2.4 & 110 \\
\hline Pigfish & $5 / 28 / 03$ & 1284 & 540 & & & & & & & \\
\hline Spot & $3 / 15 / 05$ & $\begin{array}{l}905 \\
743\end{array}$ & $\begin{array}{l}247 \\
230\end{array}$ & & & & & & & \\
\hline Pinfish & $5 / 19 / 03$ & 436 & 416 & & & & & & & \\
\hline Pinfish & $6 / 11 / 03$ & 261 & nd & & & & & & & \\
\hline Mullet & $3 / 1 / 05$ & 258 & 222 & & & & & & & \\
\hline Pigfish & $5 / 28 / 03$ & $\begin{array}{l}239 \\
222\end{array}$ & $\begin{array}{l}\text { nd } \\
199\end{array}$ & & & & & & & \\
\hline Mullet & $3 / 1 / 05$ & 170 & nd & & & & & & & \\
\hline Pinfish & $5 / 19 / 03$ & $\begin{array}{l}169 \\
142\end{array}$ & $\begin{array}{l}\text { nd } \\
\text { nd }\end{array}$ & & & & & & & \\
\hline Mullet & $3 / 15 / 05$ & 139 & nd & & & & & & & \\
\hline Mullet & $3 / 1 / 05$ & $\begin{array}{l}131 \\
120\end{array}$ & $\begin{array}{l}\text { nd } \\
\text { nd }\end{array}$ & & & & & & & \\
\hline Pinfish & $1 / 25 / 05$ & 95 & nd & & & & & & & \\
\hline Mullet & $3 / 15 / 05$ & 80 & nd & & & & & & & \\
\hline
\end{tabular}




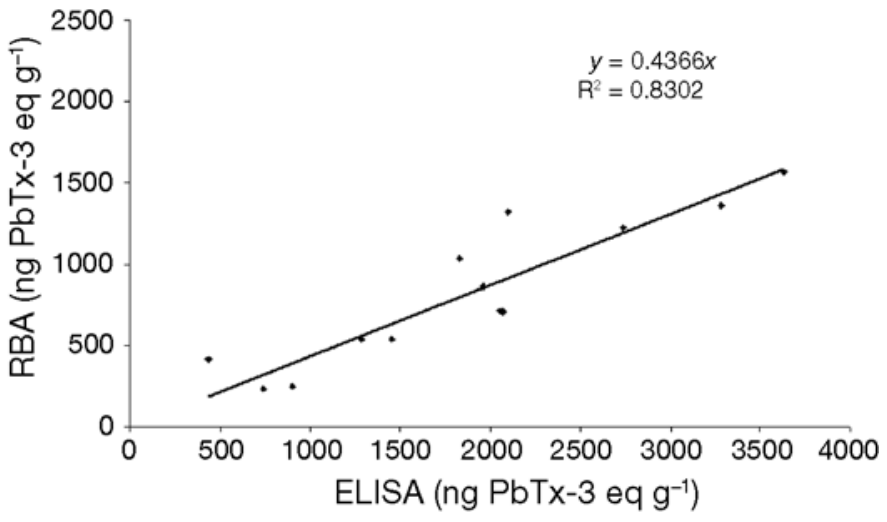

Fig. 3. Correlation of data obtained from RBA and ELISA methods for brevetoxin concentration in viscera of fish collected during Karenia brevis blooms

metabolites were detected in these samples at concentrations up to $1822 \mathrm{ng} \mathrm{g}^{-1}$, with cysteine-PbTx-B sulfoxide as the most dominant congener. The total brevetoxin content for these samples (parent $\mathrm{PbTx}+$ quantifiable metabolites) ranged in concentration from 333 to $2375 \mathrm{ng} \mathrm{g}^{-1}$.

Fish muscle, viscera and total body mass measurements were used to back-calculate brevetoxin concentrations on a whole-fish basis, in order to compare to allowable concentrations in seafood for human consumption and to estimate potential brevetoxin doses to dolphins during Karenia brevis blooms. Mean specimen weights for pinfish, pigfish and spot were 78, 113 and $54 \mathrm{~g}$, respectively, with muscle contributing between 48 and $52 \%$ and viscera contributing 6 to $8 \%$ of body mass. Based on these morphometrics and toxin data presented above, estimated brevetoxin concentrations in whole fish were greatest for pinfish $\left(433 \mathrm{ng} \mathrm{g}^{-1}\right)$, followed by spot $\left(289 \mathrm{ng} \mathrm{g}^{-1}\right)$ and pigfish $\left(287 \mathrm{ng} \mathrm{g}^{-1}\right)$.

\section{Brevetoxins in primary prey fish collected in the absence of Karenia brevis blooms}

Primary prey fish (pinfish, pigfish, striped mullet and spot) collections during June to October 2004 and May to June 2005 coincided with non-bloom intervals in the Sarasota Bay region (Fig. 2). Karenia brevis cell concentrations during these intervals were generally at or


of background cell abundance (FWRI 2008). The majority of fish from this sample set were collected between 15 and $32 \mathrm{wk}$ following the termination of the previous $K$. brevis bloom in the study area.

Analysis of these fish detected brevetoxins in the majority of specimens from each species (pinfish $88 \%$, pigfish $90 \%$, mullet $67 \%$ and spot $100 \%$ ), with $88 \%$ $(\mathrm{n}=34$ ) of all primary prey fish sampled during nonbloom intervals testing positive for brevetoxin (Table 1). Brevetoxins were detected in $96 \%(n=26)$ of viscera samples and in $20 \%$ of muscle samples ( $\mathrm{n}=25)$ at concentrations ranging from 7 to 753 (mean $=126$ ) and 3 to 14 (mean $=7$ ) ng $\mathrm{PbTx}$-eq $\mathrm{g}^{-1}$, respectively. Brevetoxin concentrations in liver, gill and stomach contents were varied, with concentrations of 21 to 1047, 34 and 45 to 263 ng PbTx-eq ${ }^{-1}$, respectively. A subset of the ELISA-positive viscera samples (84 to 461 ng PbTx-3 eq $\mathrm{g}^{-1}$ ) were analyzed by RBA, but brevetoxin was not detected above the limit of quantification of $80 \mathrm{ng} \mathrm{g}^{-1}$. Back-calculated brevetoxin concentrations on a whole-fish basis resulted in estimated brevetoxin loads of 17, 11 and $48 \mathrm{ng} \mathrm{g}^{-1}$ in pinfish, spot and pigfish, respectively.

\section{Brevetoxins in non-primary prey items in the absence of a Karenia brevis bloom}

Various species of fish, shrimp and squid were collected from Sarasota Bay during January through March 2006 and represented 33 potential and known prey species of bottlenose dolphins throughout the southeastern USA (Barros \& Odell 1990). These prey items were collected between 3 and 15 wk following the termination of the July to December 2006 Karenia brevis bloom, and corresponding cell densities at time of collection were generally at or below the detection limit of $1 \times 10^{-3}$ cells $\mathrm{l}^{-1}$. Analysis of these non-primary prey items detected brevetoxins in $65 \%(n=72)$ of all specimens collected and in $76 \%$ of the species represented (Table 3). Viscera brevetoxin content in positive specimens ranged from 13 to over $1500 \mathrm{ng} \mathrm{PbTx}-\mathrm{eq}$ $\mathrm{g}^{-1}$. All specimens that were homogenized in toto were negative for brevetoxins.

\section{DISCUSSION}

\section{Brevetoxins in primary prey fish collected during Karenia brevis blooms}

The levels of brevetoxin detected in primary prey fish collected during Karenia brevis blooms (viscera, mean $=981$ ng PbTx-3 eq $\mathrm{g}^{-1}$, max. $=5188$ ng PbTx-3 eq $\mathrm{g}^{-1}$ ) indicate a significant amount of toxin accumulation in pinfish, pigfish, spot and striped mullet. Elevated densities of $K$. brevis cells $\left(3.3 \times 10^{4}\right.$ to $5.6 \times 10^{7}$ cells $\mathrm{l}^{-1}$ ) concurrent with collection of these fish are consistent with moderate to severe bloom conditions and implicate the $K$. brevis blooms as the causative agent for toxin accumulation in the fish. These findings 
Table 3. Brevetoxin concentrations detected in non-primary prey species collected in the absence of a Karenia brevis bloom (January to March 2006). Concentrations expressed in nanograms PbTx-3 equivalents per gram sample (ng PbTx-3 eq $\mathrm{g}^{-1}$ ). nd: not detected; -: no test made

\begin{tabular}{|c|c|c|c|c|}
\hline Species name & Common name & $\mathrm{n}$ & Viscera; mean (range) & Whole fish \\
\hline Achirus lineatus & Lined sole & 2 & nd & nd \\
\hline Anchoa hepsetus & Striped anchovy & 2 & nd & - \\
\hline Ancylopsetta quadrocellata & Ocellated flounder & 1 & nd & nd \\
\hline Archosargus probatocephalus & Sheepshead & 2 & $209(207-211)$ & - \\
\hline Arius felis & Hardhead catfish & 2 & $404(356-452)$ & - \\
\hline Bagre marinus & Gafftopsail catfish & 2 & $216(203-228)$ & - \\
\hline Bairdiella chrysoura & Silver perch & 2 & $106(31-180)$ & - \\
\hline Brevoortia spp. & Menhaden & 1 & 555 & - \\
\hline Caranx hippos & Crevalle jack & 2 & 166 & nd \\
\hline Citharichthys macrops & Spotted whiff & 1 & nd & - \\
\hline Cynoscion nebulosus & Spotted seatrout & 2 & $30(29-30)$ & - \\
\hline Elops saurus & Ladyfish & 2 & $180(142-218)$ & - \\
\hline Gerreidae spp. & Mojarra & 3 & $373(255-491)$ & nd \\
\hline Harengula jaguana & Scaled sardine & 2 & 190 & nd \\
\hline Lactophrys quadricornis & Scrawled cowfish & 3 & $245(152-393)$ & - \\
\hline Lolliguncula sp. & Brief squid & 4 & - & nd \\
\hline Lutjanus griseus & Mangrove snapper & 2 & - & nd \\
\hline Lutjanus synagris & Lane snapper & 1 & - & nd \\
\hline Menticirrhus spp. & Kingfish & 2 & $748(354-1141)$ & - \\
\hline Oligoplites saurus & Leatherjacket & 3 & $148(20-352)$ & - \\
\hline Opisthonema oglinum & Atlantic thread herring & 3 & $71(70-72)$ & nd \\
\hline Opsanus beta & Gulf toadfish & 4 & $42(13-90)$ & - \\
\hline Paralichthys albigutta & Gulf flounder & 2 & 145 & nd \\
\hline Peprilus alepidotus & Harvestfish & 2 & $184(57-311)$ & - \\
\hline Pomatomus saltatrix & Bluefish & 2 & $94(78-110)$ & - \\
\hline Prionotus scitulus & Leopard searobin & 2 & 342 & nd \\
\hline Prionotus tribulus & Bighead searobin & 3 & $92(88-95)$ & nd \\
\hline Sciaenops ocellatus & Red drum & 3 & $89(76-101)$ & - \\
\hline Symphurus plagiusa & Blackcheek tonguefish & 1 & 1413 & - \\
\hline Synodus foetens & Inshore lizardfish & 3 & $221(210-232)$ & - \\
\hline Trachinotus falcatus & Permit & 2 & $>1500$ & - \\
\hline Urophycis floridana & Southern hake & 3 & $105(25-185)$ & nd \\
\hline- & Unidentified shrimp & 1 & - & nd \\
\hline
\end{tabular}

are concordant with findings of Naar et al. (2007) from near St. Joseph Bay, Florida, where $100 \%$ of the fish specimens analyzed from each species tested positive for brevetoxins in viscera samples. The detection of brevetoxins in stomach and gill samples from these fish demonstrates exposure via ingestion and respiratory pathways, respectively (Pierce et al. 2001), and brevetoxin in muscle tissue samples is an indication of bioaccumulation of the toxin (Poli et al. 1990). These results confirm that the primary prey items of Sarasota Bay area dolphins achieve elevated levels of brevetoxin during $K$. brevis blooms.

The LC-MS data show that nearly all the detectable brevetoxin present in these samples is in the form of metabolites. These metabolites can retain toxic potency and are likely to be the true cause of brevetoxin poisoning (Poli et al. 2000, Bottein-Dechraoui et al. 2007). In addition, between 35 and 63\% (mean $45 \%$ ) of the ELISA brevetoxin response in selected PbTx-positive viscera samples was detected by RBA analysis (i.e. the toxic potency of these samples was approximately half that of pure PbTx-3). These complementary LC-MS and RBA data confirm that a large portion of the total brevetoxin content in these fish (as detected by ELISA) represents pharmacologically active brevetoxin molecules that have not been completely detoxified by metabolism. Thus the brevetoxin content that is present in these fish, and therefore available for consumption by dolphins, represents a toxic food source to these dolphins.

The levels of brevetoxin detected in viscera of spot and pinfish $\left(\right.$ mean = 1982 and 1313 ng PbTx-3 eq g ${ }^{-1}$, respectively) are comparable to reported concentrations detected in fish caught live $\left(>300 \mathrm{ng} \mathrm{g}^{-1}\right.$ in spot viscera; $>400 \mathrm{ng} \mathrm{g}^{-1}$ in pinfish viscera) from St. Joseph Bay during the 2004 dolphin mortality event (Flewelling et al. 2005) and in fish from a subsequent followup study in St. Joseph Bay (386 ng g ${ }^{-1}$, spot; $1453 \mathrm{ng}$ $\mathrm{g}^{-1}$, pinfish) (Naar et al. 2007). These values are also comparable to those reported in stomach contents of 
dolphins from the 2004 mortality event (2126 $\mathrm{ng} \mathrm{g}^{-1}$; Flewelling et al. 2005) as well as to those reported in Sarasota Bay dolphin stomach contents (1142 $\mathrm{ng} \mathrm{g}^{-1}$; Fire et al. 2007). These data support previous work demonstrating that the ichthyotoxic effects of brevetoxin do not preclude its accumulation in live fish (Flewelling et al. 2005, Naar et al. 2007) and suggest that fish are potential vectors of brevetoxins to upper trophic levels.

Of the 4 prey species of interest, brevetoxin loads were greatest in whole pinfish (433 $\mathrm{ng} \mathrm{g}^{-1}$ ). The current regulatory limit in Florida for brevetoxins in seafood for human consumption is $800 \mathrm{ng} \mathrm{g}^{-1}$ (USFDA 2005). When considered in this context, these toxin loads are unlikely to constitute an acute dose. However, Karenia brevis blooms have been observed to last for 12 mo or more (Landsberg 2002), and the effects of chronic dietary exposure to strict piscivores such as Sarasota Bay dolphins are unknown. Using brevetoxin concentrations detected in prey fish, in addition to estimates of dolphin feeding rate and body mass, a total daily brevetoxin dose can be estimated for Sarasota Bay dolphins feeding on toxic fish. Previous studies estimate adult bottlenose dolphins consume 4.2 to $6.7 \%$ of their body weight daily (Young \& Phillips 2002). Adult bottlenose dolphins inhabiting Sarasota Bay have body masses between 200 and $250 \mathrm{~kg}$ (Wells $\&$ Scott 1999). Assuming these dolphins feed exclusively on pinfish (433 ng PbTx g ${ }^{-1}$ whole fish, the present study), this results in a maximum daily brevetoxin dose of $29 \mu \mathrm{g} \mathrm{PbTx} \mathrm{kg}{ }^{-1}$ body weight. This value is similar to non-lethal levels used in oral brevetoxin dosing studies with rats (18.6 $\mu \mathrm{g} \mathrm{kg}^{-1}$; Cattet \& Geraci 1993). However, these studies involved single-dose toxin administrations, and it is possible that repeat sub-acute brevetoxin exposures to dolphins over a period of months may have negative health effects less conspicuous than increased strandings and mortalities.

\section{Brevetoxins in primary and potential prey species collected in the absence of Karenia brevis blooms}

During the January to March 2006 collection, specimens from 33 non-primary prey species found in Sarasota Bay were collected within 3 to 15 wk following the termination of a particularly intense (up to $3 \times 10^{8}$ cells $\mathrm{l}^{-1}$ ) and long-lasting (>11 mo) Karenia brevis bloom. The majority of specimens and species analyzed were positive for brevetoxins and concentrations detected (13 to 1500 ng PbTx-eq $~^{-1}$ ) were comparable to those observed in primary prey species ( 7 to $753 \mathrm{ng} \mathrm{PbTx}$-eq $\mathrm{g}^{-1}$ ) collected during non-bloom intervals. Although brevetoxins were not detected in specimens that were homogenized in toto, this may have been an artifact of brevetoxins in viscera becoming diluted beyond the detection limit when combined with the more abundant muscle tissue.

Primary prey fish (pinfish, pigfish, striped mullet and spot) collected 15 to $32 \mathrm{wk}$ following the termination of a Karenia brevis bloom displayed a high prevalence of brevetoxins (88\% of specimens), although the concentrations detected were much lower than for primary prey items collected during $K$. brevis blooms. The majority $(80 \%)$ of these brevetoxin-positive specimens were collected in September to October 2004 and May to June 2006. Prior to each of these collection periods the study area had remained free of $K$. brevis blooms for a period of over 6 mo. This detection of brevetoxins in fish following a 6 mo absence of $K$. brevis blooms is supported by a growing body of work demonstrating long-term persistence of brevetoxin in marine organisms and food webs. Lipophilic molecules like brevetoxin can bioaccumulate in fish (Bottein Dechraoui et al. 2007) and are generally eliminated much more slowly than other hydrophilic harmful algal toxins (Landsberg 2002). Brevetoxins are detectable in experimentally and naturally exposed shellfish and finfish several weeks to several months post-exposure (Plakas et al. 2004, Pierce et al. 2006, Hinton \& Ramsdell 2008) and in some cases over 1 yr post-bloom (Naar et al. 2007). In southwest Florida, seagrasses also appear to have persistent detectable levels of brevetoxin in the absence of $K$. brevis blooms (L. J. Flewelling unpubl. data). With an estimated biological half-life of $229 \mathrm{~h}$ in finfish (Hinton \& Ramsdell 2008), slow depuration of brevetoxin accumulated during $K$. brevis blooms may account for some of the brevetoxin detected in fish up to several days post-bloom. However, for fish collected several months after an identifiable bloom, it is more likely that brevetoxin exposure is through unidentified yet continual toxin sources, such as food matter consumed by prey fish. The presence of brevetoxins in these prey items is consistent with previous findings that Sarasota Bay dolphins sampled during non-bloom conditions had detectable levels of the toxin in their tissues (Fire et al. 2007). These results confirm that Sarasota Bay fish associated with background $K$. brevis levels have detectable brevetoxins, and the present study offers a first step in investigating the persistence of brevetoxins in the diet of Sarasota Bay dolphins.

\section{Trophic transfer of brevetoxins}

A review of feeding habits for the primary prey fish in question may begin to address the brevetoxin levels observed in the present study for fish collected during and in the absence of Karenia brevis blooms. A common paradigm in marine mammal exposure to harmful 
algae is the trophic transfer of toxins via a short food chain, typically from toxic primary producers to end consumers mediated by a planktivorous fish vector (Anderson \& White 1989, Geraci et al. 1989, Scholin et al. 2000, Flewelling et al. 2005). However, this does not seem to be the case for the Sarasota Bay dolphin community, as none of the 4 primary prey species which compose $>80 \%$ of the dolphin diet are known to be planktivorous as adults. Although mullet exhibit planktivory as juveniles, mullet specimens collected for the present study were of the size $(270 \mathrm{~mm} \mathrm{SL})$ corresponding to detritivory and herbivory on benthic epiphytes (Bishop \& Miglarese 1978, Larson \& Shanks 1996). The size class for pigfish (96 mm SL) and spot (176 mm SL) collected in the present study corresponded to a strictly carnivorous feeding strategy, utilizing infaunal and epibenthic invertebrates such as polychaetes and amphipods (Sutter \& Mcllwain 1987, Phillips et al. 1989). Pinfish of the size range represented here (125 mm SL) have feeding habits ranging from omnivory to strict herbivory, and their diet appears to be heavily influenced by location and local food availability (Darcy 1985). The diet of pinfish from Tampa Bay, Florida (an estuarine habitat adjacent to Sarasota Bay with abundant seagrass coverage), is dominated by filamentous algae, tunicates and seagrasses (Motta et al. 1995). Collectively, it appears that trophic transfer of brevetoxin to Sarasota dolphins occurs via an indirect benthic link rather than the direct plankton grazing link commonly observed in many HAB events. Unfortunately, brevetoxin loads in detritus and benthic invertebrates during periods following $K$. brevis blooms are not known, and future work is required to assess the impact of each benthic component on toxin accumulation in this food web. However, brevetoxin concentrations of up to $1263 \mathrm{ng}$ $\mathrm{g}^{-1}$ have been detected in Florida seagrasses Thalassia testudinum (Flewelling et al. 2005), and these are a likely post-bloom brevetoxin source to pinfish in this region, since they are primarily herbivorous and are associated with seagrasses for most of their life history (Luczkovich \& Stellwag 1993, Luczkovich et al. 1995). Furthermore, since pinfish (1) had the highest wholefish brevetoxin concentrations in the present study, (2) are the most common and most numerically abundant fish in the diet of Sarasota Bay dolphins (Barros \& Wells 1998) and (3) have an abundant toxic food source, this species of fish in particular has significant potential to transfer brevetoxins to higher trophic levels and suggests that pinfish are an important brevetoxin vector to dolphins in this region.

The presence and persistence of brevetoxins in primary prey fish collected during and following Karenia brevis blooms suggests long-term availability of toxic food items to Sarasota Bay dolphins. Although the con- centrations detected in the present study were likely not acute levels, persistence of brevetoxin in the dolphin diet constitutes a potential health risk, and further investigation of this food web will benefit conservation efforts. Acute exposure to dolphins during severe blooms is positively correlated to increased stranding frequency and mortality (Fauquier et al. 2005), but less is known about long-term, sublethal exposure. Chronic exposure of marine mammals to brevetoxin may result in immunological compromise which can in turn lead to other deleterious health effects (Bossart et al. 1998).

The present study demonstrates that, similar to fish from the St. Joseph Bay area (Flewelling et al. 2005, Naar et al. 2007), primary prey fish of Sarasota Bay dolphins can accumulate high concentrations of brevetoxins during Karenia brevis blooms. Fish collected in the absence of $K$. brevis blooms also contain detectable levels of brevetoxins, and the present study is the first to quantify non-bloom concentrations of brevetoxins in Sarasota Bay fish. Given their predominance in the diet of long-term, year-round resident Sarasota Bay dolphins (Barros \& Wells 1998, Wells 2003), pinfish are a potential brevetoxin vector during $K$. brevis blooms and can accumulate brevetoxins in concentrations comparable to fish implicated as vectors in large-scale dolphin mortality events. The present study emphasizes the importance of investigating the feeding habits of animals involved in bloom-associated mortalities in order to establish specific routes of toxin trophic transfer from phytoplankton to top consumers. Understanding the capacity of the benthic component of this food web to accumulate brevetoxins is critical in predicting the exposure of Sarasota Bay dolphins to the harmful effects of $K$. brevis blooms. Additional studies determining all stages of trophic transfer of brevetoxins from $K$. brevis to top-level predators are needed, given the scarcity of available data on toxin loads in many organisms. Specifically, studies comparing toxin accumulation rates and persistence in zooplankton, detritus, fish, invertebrates and seagrass species are necessary for comparing toxin exposure between dolphin populations with different feeding habits. Brevetoxin exposure is more complex than a linear response to increased $K$. brevis cell densities and involves the interaction of various feeding strategies at multiple trophic levels. Once the fate of brevetoxins produced in a bloom is known and the distribution of toxin among the various organisms is established, researchers can more effectively determine the degree of exposure to dolphins in the context of their ranging patterns, feeding strategies and prey choice.

Acknowledgements. The authors thank E. Berens, S. Camilleri, K. Brueggen and A. Barleycorn for fish and water sample collections. We thank G. Kirkpatrick and V. Palubok for use 
of $K$. brevis cell abundance data and laboratory assistance. We are grateful to T. Blum, D. Wetzel, P. Mercurio, C. Luer, C. Walsh, S. Hamel, C. Higham and K. Lemkau for logisti$\mathrm{cal}$ and/or laboratory assistance and use of instrumentation. We thank M. Silver, D. Costa, N. Barros, D. Fauquier, L. Schwacke, T. Leighfield and F. Van Dolah for assistance in manuscript preparation, experimental design and/or discussions. We also thank F. Radwan, E. Zolman, M. Y. Bottein and J. Ramsdell for comments on the manuscript. Fish were collected under Mote Marine Laboratory IACUC protocols and Florida Fish and Wildlife Conservation Commission Special Activity Licenses (SAL \# 03SR-809 and 04SR-809) issued to D.P.G. This research was supported by funding from Long Marine Laboratory, Disney Wildlife Conservation Fund, National Marine Fisheries Service, Florida Fish and Wildlife Conservation Commission, Harbor Branch Oceanographic Institution and the Chicago Zoological Society.

\section{LITERATURE CITED}

Abraham A, Plakas SM, Wang Z, Jester ELE and others (2006) Characterization of polar brevetoxin derivatives isolated from Karenia brevis cultures and natural blooms. Toxicon 48:104-115

Anderson DM, White AW (1989) Toxic dinoflagellates and marine mammal mortalities. Tech Rep WHOI-89-36, Woods Hole Oceanographic Institution, Woods Hole, MA

Barros NB, Odell DK (1990) Food habits of bottlenose dolphins in the southeastern United States. In: Leatherwood $\mathrm{S}$, Reeves RR (eds) The bottlenose dolphin. Academic Press, San Diego, CA, p 309-328

Barros NB, Wells RS (1998) Prey and feeding patterns of resident bottlenose dolphins (Tursiops truncatus) in Sarasota Bay, Florida. J Mammal 79:1045-1059

Bishop JM, Miglarese JV (1978) Carnivorous feeding in adult striped mullet. Copeia 1978:705-707

Bossart GD (2006) Marine mammals as sentinel species for oceans and human health. Oceanography (Wash DC) 19: $134-137$

Bossart GD, Baden DG, Ewing RY, Roberts B, Wright SD (1998) Brevetoxicosis in manatees (Trichechus manatus latirostris) from the 1996 epizootic: gross, histologic, and immunohistochemical features. Toxicol Pathol 26:276-282

Bottein Dechraoui MY, Wang Z, Ramsdell JS (2007) Intrinsic potency of synthetically prepared brevetoxin cysteine metabolites BTX-B2 and desoxyBTX-B2. Toxicon 50: 825-834

Cattet M, Geraci JR (1993) Distribution and elimination of ingested brevetoxin (PbTx-3) in rats. Toxicon 31: 1483-1486

Collins MR (1985) Species profiles: life histories and environmental requirements of coastal fishes and invertebrates (South Florida) - striped mullet. US Fish Wildl Serv Biol Rep 82(11.34). US Army Corps of Engineers, TR EL-82-4, Fort Collins, CO

Darcy GH (1985) Synopsis of biological data on the pinfish, Lagodon rhomboides (Pisces: Sparidae). NOAA Tech Rep NMFS 23

Daugbjerg N, Hansen G, Larsen J, Moestrup O (2000) Phylogeny of some of the major genera of dinoflagellates based on ultrastructure and partial LSU rDNA sequence data, including the erection of three new genera of unarmoured dinoflagellates. Phycologia 39:302-317

> Dechraoui MYB, Tiedeken JA, Persad R, Wang Z, Granade HR, Dickey RW, Ramsdell JS (2005) Use of two detection methods to discriminate ciguatoxins from brevetoxins: application to great barracuda from Florida Keys. Toxicon 46:261-270

Fauquier DA, Fire S, Flewelling L, Pierce R and others (2005) Brevetoxin induced morbidity and mortality in stranded and wild dolphins from central west Florida. Final Technical Report to Harbor Branch Oceanographic Institution's PWD Program, Fort Pierce, FL

Fire SE, Fauquier D, Flewelling LJ, Henry M, Naar J, Pierce R, Wells RS (2007) Brevetoxin exposure in bottlenose dolphins (Tursiops truncatus) associated with Karenia brevis blooms in Sarasota Bay, Florida. Mar Biol 152:827-834

- Flewelling LJ, Naar JP, Abbott JP, Baden DG and others (2005) Red tides and marine mammal mortalities. Nature 435:755-756

Forrester DJ, Gaskin JM, White FH, Thompson NP and others (1977) An epizootic of waterfowl associated with a red tide episode in Florida. J Wildl Dis 13:160-167

FWRI (Fish and Wildlife Research Institute) (2008) Red tide current status statewide information. FWRI, St Petersburg, FL. Available at: http://research.myfwc.com/features/ view_article.asp?id=9670

Geraci JR (1989) Clinical investigation of the 1987-88 mass mortality of bottlenose dolphins along the US central and south Atlantic coast. Final Report to the National Marine Fisheries Service, US Navy Office of Naval Research and Marine Mammal Commission, Ontario Veterinary College, University of Guelph, Guelph

Geraci JR, Anderson DM, Timperi RJ, St. Aubin DJ, Early GA, Prescott JH, Mayo CA (1989) Humpback whales (Megaptera novaeangliae) fatally poisoned by dinoflagellate toxin. Can J Fish Aquat Sci 46:1895-1898

Gunter G, Williams RH, Davis CC, Smith FGW (1948) Catastrophic mass mortality of marine animals and coincident phytoplankton bloom on the west coast of Florida, November 1946 to August 1947. Ecol Monogr 18:309-324

Hallegraeff GM (2003) Harmful algal blooms: a global overview. In: Hallegraeff GM, Anderson DM, Cembella $\mathrm{AD}$ (eds) Manual on harmful marine microalgae. Monogr Oceanogr Method 11:25-49

> Hinton M, Ramsdell JS (2008) Brevetoxin in two planktivorous fishes after exposure to Karenia brevis: implications for food-web transfer to bottlenose dolphins. Mar Ecol Prog Ser 356:251-258

Irvine AB, Scott MD, Wells RS, Kaufmann JH (1981) Movements and activities of the Atlantic bottlenose dolphin, Tursiops truncatus, near Sarasota, Florida. Fish Bull (Wash DC) 79:671-688

> Landsberg JH (2002) The effects of harmful algal blooms on aquatic organisms. Rev Fish Sci 10:113-390

Landsberg JH, Steidinger KA (1998) A historical review of Gymnodinium breve red tides implicated in mass mortalities of the manatee (Trichechus manatus latirostris) in Florida, USA. In: Reguera B, Blanco J, Fernandez ML, Wyatt T (eds) Harmful algae. Xunta de Galicia and Intergovernmental Oceanographic Commission, UNESCO, Vigo, p 97-100

Larson ET, Shanks AL (1996) Consumption of marine snow by two species of juvenile mullet and its contribution to their growth. Mar Ecol Prog Ser 130:19-28

Lefebvre KA, Powell CL, Busman M, Doucette GJ and others (1999) Detection of domoic acid in northern anchovies and California sea lions associated with an unusual mortality event. Nat Toxins 7:85-92

> Luczkovich JJ, Stellwag EJ (1993) Isolation of cellulolytic microbes from the intestinal tract of the pinfish, Lagodon rhomboides: size-related changes in diet and microbial abundance. Mar Biol 116:381-388 
Luczkovich JJ, Norton SR, Gilmore RG (1995) The influence of oral anatomy on prey selection during the ontogeny of two percoid fishes, Lagodon rhomboides and Centropomus undecimalis. Environ Biol Fishes 44:79-95

Mase B, Jones W, Ewing R, Bossart G and others (2000) Epizootic in bottlenose dolphins in the Florida panhandle: 1999-2000. In: Baer CK (ed) Proc Am Assoc Zoo Vet Int Assoc Aquat Anim Med. American Association of Zoo Veterinarians, Yulee, FL, p 522-525

Motta PJ, Clifton KB, Hernandez P, Eggold BT, Giordano SD, Wilcox R (1995) Feeding relationships among nine species of seagrass fishes of Tampa Bay, Florida. Bull Mar Sci 56: $185-200$

Murata K, Satake M, Naoki H, Kaspar HF, Yasumoto T (1998) Isolation and structure of a new brevetoxin analog, brevetoxin B2, from greenshell mussels from New Zealand. Tetrahedron Lett 54:735-742

Naar J, Bourdelais A, Tomas C, Kubanek J and others (2002) A competitive ELISA to detect brevetoxins from Karenia brevis (formerly Gymnodinium breve) in seawater, shellfish, and mammalian body fluid. Environ Health Perspect 110:179-185

Naar JP, Flewelling LJ, Lenzi A, Abbott JP and others (2007) Brevetoxins, like ciguatoxins, are potent ichthyotoxic neurotoxins that accumulate in fish. Toxicon 50: $707-723$

NMFS (2004) Interim report on the bottlenose dolphin (Tursiops truncatus) unusual mortality event along the Panhandle of Florida, March-April 2004. NMFS, Southeast Fisheries Science Center, Miami, FL

NOAA OPR (NOAA Fisheries Office of Protected Resources) (2008) Marine mammal unusual mortality events. Available at www.nmfs.noaa.gov/pr/health/mmume

O'Shea TJ, Rathbun GB, Bonde RK, Buergelt CD, Odell DK (1991) An epizootic of Florida manatees associated with a dinoflagellate bloom. Mar Mamm Sci 7:165-179

Phillips JM, Huish MT, Kerby JH, Moran DP (1989) Species profiles; life histories and environmental requirements of coastal fishes and invertebrates (Mid-Atlantic) - spot. US Fish Wildl Serv Biol Rep 82(11.98). US Army Corps of Engineers, TR EL-82-4

Pierce R, Henry M, Blum P, Payne S (2001) Gymnodinium breve toxins without cells: intracellular and extra-cellular toxins. In: Hallegraeff GM, Blackburn SI, Bolch CJ, Lewis RJ (eds) Harmful algal blooms 2000. IOC of UNESCO, Paris, p 421-424

Pierce RH, Henry MS, Blum PC, Plakas SM and others (2006) Comparison of methods for determination of brevetoxins and their metabolites in NSP-toxic bivalved molluscs. In: Henshilwood K, Deegan B, McMahon T, Cusack C and others (eds) Proc 5th Int Conf Molluscan Shellfish Safety, June 14-18, 2004. The Marine Institute, Galway, p 37-42. Available at: www.marine.ie/home/publicationsdata/ publications/MEHS.htm

Plakas SM, El Said KR, Jester ELE, Granade HR, Musser SM, Dickey RW (2002) Confirmation of brevetoxin metabolism in the Eastern oyster (Crassostrea virginica) by controlled exposures to pure toxins and to Karenia brevis cultures. Toxicon 40:721-729

Plakas SM, Wang Z, El Said KR, Jester ELE and others (2004) Brevetoxin metabolism and elimination in the Eastern oyster (Crassostrea virginica) after controlled exposures to Karenia brevis. Toxicon 44:677-685

Poli MA, Mende TJ, Baden DG (1986) Brevetoxins, unique activators of voltage-sensitive sodium channels, bind to specific sites in rat brain synaptosomes. Mol Pharmacol 30: 129-135

Poli MA, Templeton CB, Thompson WL, Hewetson JF (1990) Distribution and elimination of brevetoxin PbTx-3 in rats. Toxicon 28:903-910

Poli MA, Musser SM, Dickey RW, Eilers PP, Hall S (2000) Neurotoxic shellfish poisoning and brevetoxin metabolites: a case study from Florida. Toxicon 38:981-993

Scholin CA, Gulland F, Doucette GJ, Benson S and others (2000) Mortality of sea lions along the central California coast linked to a toxic diatom bloom. Nature 403:80-84

Shimizu Y, Gupta S, Hong-Nong C (1990) Biosynthesis of red tide toxins. In: Hall S, Strichartz G (eds) Marine toxins: origin, structure and molecular pharmacology. American Chemical Society, Washington, DC, p 21-28

Steidinger KA, Vargo GA, Tester PA, Tomas CR (1998) Bloom dynamics and physiology of Gymnodinium breve with emphasis on the Gulf of Mexico. In: Anderson DM, Cembella AD, Hallegraeff GM (eds) Physiological ecology of harmful algal blooms. Springer-Verlag, Berlin, p 133-153

Sutter FC, McIlwain TD (1987) Species profiles; life histories and environmental requirements of coastal fishes and invertebrates (Gulf of Mexico) - pigfish. US Fish Wildl Serv Biol Rep 82(11.71). US Army Corps of Engineers, TR EL-82-4

Tester PA, Turner JT, Shea D (2000) Vectorial transport of toxins from the dinoflagellate Gymnodinium breve through copepods to fish. J Plankton Res 22:47-61

USFDA (2005) National shellfish sanitation program guide for the control of molluscan shellfish. US Food and Drug Administration, Center for Food Safety and Applied Nutrition, Washington, DC

Van Dolah FM (2000) Marine algal toxins: origins, health effects, and their increased occurrence. Environ Health Perspect 108:133-141

> Van Dolah FM, Ramsdell JS (2001) Review and assessment of in vitro detection methods for algal toxins. J Assoc Off Anal Chem Int 84:1617-1625

- Van Dolah FM, Finley EL, Haynes BL, Doucette GJ, Moeller PD, Ramsdell JS (1994) Development of rapid and sensitive high throughput pharmacologic assays for marine phycotoxins. Nat Toxins 2:189-196

Walker ST (1884) Fish mortality in the Gulf of Mexico. Proc US Natl Mus 6:105-109

Wang Z, Plakas SM, El Said KR, Jester ELE, Granade HR, Dickey RW (2004) LC/MS analysis of brevetoxin metabolites in the Estern oyster (Crassostrea virginica). Toxicon 43:455-465

Wells RS (2003) Dolphin social complexity: lessons from longterm study and life history. In: de Waal FBM, Tyack PL (eds) Animal social complexity: intelligence, culture, and individualized societies. Harvard University Press, Cambridge, MA, p 32-56

Wells RS, Scott MD (1999) Bottlenose dolphin Tursiops truncatus (Montagu, 1821). In: Ridgway SH, Harrison R (eds) Handbook of marine mammals, Vol 6: the second book of dolphins and porpoises. Academic Press, San Diego, CA, p 137-182

Woofter RT, Brendtro K, Ramsdell JS (2005) Uptake and elimination of brevetoxin in blood of striped mullet (Mugil cephalus) after aqueous exposure to Karenia brevis. Environ Health Perspect 113:11-16

> Young RF, Phillips HD (2002) Primary production required to support bottlenose dolphins in a salt marsh estuarine creek system. Mar Mamm Sci 18:358-373 